\title{
O PODER DO ESTADO NO USO DA VIOLÊNCIA LEGITIMA: UM OLHAR SOBRE O SISTEMA PRISIONAL BRASILEIRO E SUA (IN)EFETIVIDADE
}

\begin{abstract}
Giovanni Olsson
Doutor em Direito pela Universidade Federal de Santa Catarina (UFSC) de Florianópolis/ Santa Catarina. Vice-Líder e Pesquisador do Grupo de Pesquisa Relações Internacionais, Direito e Poder (CNPQ). Professor Permanente do Programa de Mestrado em Direito da Universidade Comunitária da Região de Chapecó (Unochapecó) de Chapecó/Santa Catarina, na linha Atores Internacionais. E-mail: <golsson71@gmail.com>.
\end{abstract}

\section{Valquíria Castaldi}

Mestranda em Direito. Especialista em Ciências Criminais. Graduada em Direito pela Universidade Comunitária da Região de Chapecó (Unochapecó) de Chapecó/ Santa Catarina. Pesquisadora do Grupo de Pesquisa Relações Internacionais, Direito e Poder (CNPQ). Bolsista Integral da Universidade Comunitária da Região de Chapecó (Unochapecó) de Chapecó/Santa Catarina. E-mail: <valquíria.castaldi@gmail.com>.

\begin{abstract}
Resumo: O presente artigo tem por objetivo principal compreender como o Estado, no uso de seu poder soberano, faz uso da violência legítima, especialmente na aplicação da pena privativa de liberdade no sistema prisional. Para isso, necessário se faz compreender as concepções modernas de poder, a constituição do Estado, a violência e a sua relação com o poder para que seja entendida como legítima, as teorias que defendem a aplicação mínima e máxima do direito penal, assim como a crise pela qual passa a pena privativa de liberdade e o sistema prisional. Para o desenvolvimento do presente artigo, a metodologia adotada é a revisão bibliográfica e o método dedutivo.
\end{abstract}

Palavras-chave: Poder. Estado-Nação. Violência. Prisão.

Sumário: 1 Considerações iniciais - $\mathbf{2} 0$ poder como categoria em evolução - $\mathbf{3} 0$ Estado-Nação e a violência legítima - 4 A pena privativa de liberdade e as prisões - 5 Abolicionismo penal e minimalismo versus direito penal máximo e direito penal do inimigo - $\mathbf{6} 0$ sistema prisional brasileiro e a seletividade penal - $\mathbf{7}$ Considerações finais - Referências 


\section{Considerações iniciais}

O poderé inerente aos indivíduos e já estava presente nas relações entre grupos muito antes da constituição do Estado. Não por acaso, os estudiosos atribuem a ele diversos conceitos, âmbitos de exercício e formas de desenvolvimento.

Os indivíduos que viviam em estado de natureza constituem o Estado ao abrirem mão de parcela de seu poder e ao destinarem a um ente que tinha por intenção representar a todos e garantir o bem comum. O Estado, imbuído desse poder, então, incorpora como um de seus mecanismos de atuação exatamente 0 uso da violência legítima para o controle social.

A pena privativa de liberdade, aplicada pelos sistemas judiciários como um desdobramento desse poder, é a resposta mais expressiva dada pela sociedade ao indivíduo autor de uma infração penal. Com a intensificação da aplicação das penas privativas de liberdade, por sua vez, consolidou-se e expandiu-se o sistema prisional como complexo de estruturas e funcionalidades com o fim de realizar os objetivos da pena.

No entanto, apesar de sua vasta aplicação, a pena privativa de liberdade sofre grandes críticas da sociedade, associadas particularmente à crise vivenciada no sistema prisional brasileiro. Essas críticas dão fundamento às teorias abolicionistas e minimalistas, mas existe ainda forte defesa para a aplicação máxima do direito penal como uma resposta à necessidade de controle social.

Diversas circunstâncias conjugadas, como a seletividade do sistema voltada para as classes sociais mais baixas, as precárias condições físicas das instalações e os altos índices de reincidência dentro do sistema prisional, demonstram claramente o descumprimento da Lei de Execução Penal brasileira e o seu distanciamento dos fins aos quais o sistema prisional se propõe.

Considerando que alguns dos principais instrumentos de violência legítima estatal são o uso do sistema prisional e a imposição de penas privativas de liberdade, o presente artigo pretende verificar como o Estado, no uso de seu poder, legitima o uso da violência para com seus cidadãos, submetendo-os a um sistema falido e desumano.

Para o desenvolvimento deste trabalho, analisam-se os temas do poder, Estado-Nação, violência, sistema prisional e seletividade penal, os quais são abordados em cinco tópicos: o primeiro tratará sobre o poder como categoria em evolução, apontando os conceitos de "poder para" e "poder sobre"; no segundo tópico, será apresentado o conceito de Estado-Nação e como este faz uso da violência legítima; o terceiro abordará a finalidade e a efetividade da pena privativa de liberdade e das prisões; no quarto tópico, serão analisados os principais aspectos do debate entre o abolicionismo e as concepções do direito penal mínimo, de um 
lado, e a maximização do controle penal e do direito penal do inimigo, de outro. Por fim, contextualizar-se-ão a atual situação do sistema prisional e a seletividade penal como uma consequência do sistema penal brasileiro.

Para o desenvolvimento da presente pesquisa, optou-se pelo método dedutivo, tendo a pesquisa um caráter qualitativo, adotando-se a técnica da pesquisa bibliográfica baseada na literatura especializada.

\section{0 poder como categoria em evolução}

O poder é um tema discutido em nossa sociedade há muito tempo. Dentre os principais autores que o debateram em diversos momentos da história e de variadas perspectivas, podem-se citar Max Weber, Thomas Hobbes, Michel Foucault e Pierre Bourdieu.

Para enfrentar o tema, elaborar-se-á uma categorização conceitual do poder na visão dos autores acima citados para que, em um segundo momento, se possa adentrar na interpretação do desenvolvimento do poder na sociedade com base na contemporânea distinção de "poder sobre" e "poder para" para, ao final, investigar o específico uso do "poder sobre" por parte do Estado no sistema penal.

De início e na concepção de Hobbes, ${ }^{1}$ um dos primeiros a estudar o tema no âmbito do Estado, um homem pode ter poderes naturais (qualidades eminentes à sua personalidade ou tipo físico) ou instrumentais (os artifícios de que se dispõem para obtenção de outros tipos de vantagens). Todavia, o poder de maior importância entre todos os tipos existentes seria aquele composto pela união dos poderes de diversos homens e concedidos a um único homem, natural ou civil, referindo-se, neste caso, ao poder detido pelo Estado, ou seja, o poder absoluto do Estado, na pessoa de seu representante.

Por sua vez, Weber ${ }^{2}$ trata dos aspectos relativos ao poder, à dominação e à disciplina. Para ele, basicamente, o poder é a possibilidade de imposição de vontade, a dominação é a obediência a uma ordem, e a disciplina é o treinamento ao ato de obedecer. Nesse sentido, conceitua poder como "toda probabilidade de impor a própria vontade numa relação social, mesmo contra resistências, seja qual for o fundamento dessa probabilidade"; a dominação como a "probabilidade de encontrar obediência a uma ordem de determinado conteúdo, entre determinadas

1 HOBBES, Thomas. Leviatã ou matéria, forma e poder de um estado eclesiástico e civil. Tradução de João Paulo Monteiro e Maria Beatriz Nizza da Silva. São Paulo: Abril Cultural, 1979. p. 53.

2 WEBER, Max. Economia e sociedade: fundamentos da sociologia compreensiva. Volume I. Tradução de Regis Barbosa e Karen Elsabe Barbosa. Brasília, DF: Editora Universidade de Brasília: São Paulo: Imprensa Oficial do Estado de São Paulo, 1999a. p. 33. 
pessoas indicáveis"; e, por fim, a disciplina como a "probabilidade de encontrar obediência pronta, automática e esquemática a uma ordem, entre uma pluralidade indicável de pessoas, em virtude de atividades treinadas".

Para Foucault, ${ }^{3}$ a seu turno, o poder tem em sua essência a característica repressora, e a ele cabe a opressão da natureza, dos instintos, dos indivíduos e de uma classe. 0 poder é uma relação de força entre duas partes, mas, na esfera jurídica, o poder é um direito que o indivíduo possui, assim como tem propriedade sobre um bem para aliená-lo total ou parcialmente.

Bourdieu, ${ }^{4}$ sob outro prisma, vislumbra as relações de poder com base nos símbolos, denominando-o de "poder simbólico". Assim, o autor refere-se a "aquele poder invisivel que somente pode ser exercido com a cumplicidade daqueles que não querem saber que se lhe estão sujeitos ou mesmo que o exercem". Diante desse conceito, pode-se verificar que o poder simbólico está vinculado à subjetividade humana e à interação com a realidade por meio das construções simbólicas estruturadas dentro das relações sociais. As relações entre poder e simbologia estão em todos os lugares, mas se evidenciam em esferas como a arte, a religião e a linguagem. Essa função social do símbolo é atuar como instrumento da integração coletiva, tornando possível a materialização do poder por meio dos símbolos que o representam, como o padre e a sua batina frente aos fiéis, o médico e a sua vestimenta branca em relação ao paciente, ou o policial e a sua farda frente aos cidadãos. Os símbolos demonstram, assim, nada mais do que a distribuição de poder entre os diferentes papéis desenvolvidos pelos indivíduos no seio de uma sociedade.

As concepções de poder apresentadas por Thomas Hobbes ${ }^{5}$ e Max Weber, ${ }^{6}$ nas quais fica claro o uso do poder de forma impositiva, vertical e coercitiva, resultando na dominação daqueles que são submetidos ao exercício do poder, ou do mais forte em relação ao mais fraco, permitem identificar uma espécie muito característica de poder que passou a ser depois conhecida como "poder sobre". Alguns exemplos dessa forma de exercício do poder são a imposição de vontade do pai em relação aos filhos, a dominação do policial em relação ao preso, a

3 FOUCAULT, Michel. Microfísica do poder. Trad. Roberto Machado. 14. ed. Rio de Janeiro: Edições Graal, 1999. p. 174-176.

4 BOURDIEU, Pierre. Language and symbolic power. Edited and introduced by John B. Thompson. Translated by Gino Raymond and Matthew Adams. Oxford: Polity Press, 1991. p. 164-166.

5 HOBBES, Thomas. Leviatã ou matéria, forma e poder de um estado eclesiástico e civil. Tradução de João Paulo Monteiro e Maria Beatriz Nizza da Silva. São Paulo: Abril Cultural, 1979. p. 64.

6 WEBER, Max. Economia e sociedade: fundamentos da sociologia compreensiva. Volume I. Tradução de Regis Barbosa e Karen Elsabe Barbosa. Brasília, DF: Editora Universidade de Brasília: São Paulo: Imprensa Oficial do Estado de São Paulo, 1999a. p. 33. 
imposição das decisões do Estado em relação aos seus cidadãos, entre outras, resultando em uma relação de dominação pelo comando e a obediência.

Já no que se refere aos conceitos trazidos por Michel Foucault ${ }^{7}$ e Pierre Bourdieu, ${ }^{8}$ percebe-se que o poder para eles pode ser caracterizado como um tipo de "poder para”, visto que, além de condicionar e regular as ações dos indivíduos, é resultado do diálogo e consenso social. Assim, o poder se desenvolveria além dos parâmetros de submissão e dominação, difundindo-se por meio do conhecimento e transformando a realidade social mediante a construção conjunta dos indivíduos, ou seja, a sociedade civil organizada, não estando apenas nas mãos do Estado e, mais, não sendo necessariamente opressor e verticalizado no sentido descendente. Podem-se citar, como exemplos, as deliberações feitas em assembleias e até mesmo o orçamento participativo.

A diferenciação entre as duas vertentes acima apresentadas de "poder sobre" e "poder para" foi introduzida por Hannah Pitkin ${ }^{9}$ pioneiramente. Assim, tem-se o "poder sobre" como um elemento relacional, e o "poder para" desenvolvido na ação social e política.

A categorização do "poder para” encontra força também nos postulados de Parsons, ${ }^{10}$ que considera que o poder tem um caráter de construção do consenso social, muito além da regulação de conflitos. Em sua concepção, Parsons defende que o domínio de poder por um indivíduo não exclui a parcela de poder dominado por outro indivíduo, mas que o poder é produzido e construído por meio do diálogo e consenso social. Assim, conclui-se que o "poder para" é aquele resultante da construção coletiva e para atingir fins coletivos. Caracteriza-se pelo poder emanado pela sociedade civil organizada por meio dos movimentos sociais e até mesmo nas decisões de órgãos colegiados e na democracia participativa.

No que tange ao conceito de "poder sobre", este se caracteriza pela relação de comando e obediência, como instrumento de dominação social que funciona "sobre" os sujeitos, ou seja, na realização da vontade um indivíduo mesmo contra a resistência, independentemente de seu fundamento. 0 "poder sobre", reconhecido por Weber ${ }^{11}$ como coercitivo, impositivo e dominante, representado

7 FOUCAULT, Michel. Power and knowledge: selected interviews and other writings 1972-1977. Edited by Colin Gordon. Transl. by Colin Gordon et al. New York: Pantheon, 1980. p. 72.

8 BOURDIEU, Pierre. Language and symbolic power. Edited and introduced by John B. Thompson. Translated by Gino Raymond and Matthew Adams. Oxford: Polity Press, 1991. p. 166.

9 PITKIN, Hanna Fenichel. Wittgenstein and Justice: on the significance of Ludwig Wittgenstein for social and political thought. Berkeley: University of California Press, 1972. p. 276.

10 PARSONS, Talcott. Sociological theory and modern society. New York: The Free Press, 1967. p. 308.

11 WEBER, Max. Economia e sociedade: fundamentos da sociologia compreensiva. Volume I. Tradução de Regis Barbosa e Karen Elsabe Barbosa. Brasília, DF: Editora Universidade de Brasília; São Paulo: Imprensa Oficial do Estado de São Paulo, 1999a. p. 33. 
genericamente pela força militar, tem como principal exemplo o Estado nos seus atos de império.

Concluída esta breve apresentação sobre os tipos de poder que permeiam a vida social nas suas classificações contemporâneas, segue-se no presente trabalho o foco de estudo do "poder sobre", que é, no âmbito deste estudo, delimitado sobre aquele exercido pelo Estado sobre os indivíduos. Assim, temse que o Estado, ao exercer o seu "poder sobre", tem por um de seus objetivos o controle social, o que envolve, não raras vezes, o poder de aplicar formas violentas de controle, que, por serem veiculadas pelo Leviatã, recebem o atributo de violência legítima. Não por acaso, um de seus maiores instrumentos para realizar esse controle social é o sistema penal, por meio da fiscalização policial, de investigações, da aplicação de penalidades e, no extremo, da restrição de liberdade dos indivíduos.

Com base em tais postulados, é possível verificar que o Estado-Nação, como o principal detentor desse tipo de poder, ao exercer, coercitivamente, o seu "poder sobre", deve fazer uso da sua violência de forma legítima quando empregada em seu nome e em favor do interesse da coletividade, como se tentará melhor explicitar no tópico a seguir.

\section{Estado-Nação e a violência legítima}

Uma das vertentes mais fortes sobre a origem do Estado é a chamada “contratualista", que sustenta o surgimento do Estado a partir da necessidade de regulação e mediação das relações entre os indivíduos que conviviam em estado de natureza, delegando poder a uma terceira pessoa para que regulamentasse as interações em grupo. Isso faria desse grupo uma sociedade e limitaria a liberdade de cada indivíduo até o limite da liberdade do outro, como cláusulas de um contrato entre todos celebrado.

O Estado-Nação, assim, segundo Thomas Hobbes, ${ }^{12}$ seria constituído da necessidade de limitação e regulação da liberdade dos indivíduos que estão em estado de natureza, e essa constituição se dá no momento em que os indivíduos abrem mão da sua liberdade, desistem do direito de governar a si mesmos e conferem a um homem ou a uma assembleia de homens toda a força e poder para todas as decisões e representação de todos, visando ao bem comum. Dessa união dos indivíduos em uma só pessoa, forma-se o Estado e, portanto, é gerado

12 HOBBES, Thomas. Leviatã ou matéria, forma e poder de um estado eclesiástico e civil. Tradução de João Paulo Monteiro e Maria Beatriz Nizza da Silva. São Paulo: Abril Cultural, 1979. p. 103-106. 
o grande Leviatã como um Deus mortal que está abaixo apenas de Deus imortal e tem por função garantir a paz e defesa dos indivíduos. Assim, a "autorização que cada indivíduo dá ao Estado o direito de usar todo o poder e a força, esse Estado, pelo temor que inspira, é capaz de conformar todas as vontades, a fim de garantir a paz em seu país, e promover a ajuda mútua contra os inimigos estrangeiros".

Na concepção de Weber, ${ }^{13}$ por sua vez, o Estado racional-legal é consolidado com base em uma comunidade de indivíduos que objetiva o monopólio do uso legítimo da força física em determinado território, sendo o Estado a única fonte do direito com capacidade para uso da violência, considerada legítima, em consequência de uma relação de dominação de um homem para com outros homens. Seguindo a corrente contratualista, Weber sustenta que é pressuposto da existência de um Estado que os cidadãos que o compõem obedeçam à autoridade exercida pelos detentores do poder enquanto representantes desse Estado e, ainda, para que haja obediência, é necessário que a autoridade seja reconhecida como legítima, visto que seu processo de empoderamento se deu pela concessão dos poderes individuais de cada um para o ente estatal.

Mesmo que o papel do Estado hoje possa ser relativizado pela globalização e emergência de outros atores no cenário internacional, particularmente as poderosas corporações transnacionais, não restam dúvidas de que o poder por ele exercido consiste em utilizar-se de sua autoridade para sujeitar os indivíduos em nome do interesse coletivo. Essa relação de sujeição é uma das principais características do "poder sobre" enquanto detentor da maior força (militar ou política) quando em conflito com o mais fraco, o indivíduo, resultando no uso da violência legítima. ${ }^{14}$

É dessa concessão de poder pelos indivíduos ao Estado que emerge a legitimidade a todos os seus atos, mesmo que estes atos façam uso da força e sejam até considerados violentos.

O Estado tem a posse de um território e a regência dos indivíduos que ali residem. Portanto, exerce seu poder com a utilização de instituições jurídicas, administrativas, políticas, econômicas e policiais. Internamente, a imposição do poder estatal ocorre pela determinação das leis e exigência de seu cumprimento, pela punição daqueles que as descumprirem, entre outros expedientes. Para isso, o Estado faz uso de diversos mecanismos como tribunais, corporação policial e

13 WEBER, Max. Economia e sociedade: fundamentos da sociologia compreensiva. Volume II. Tradução de Regis Barbosa e Karen Elsabe Barbosa. Brasília, DF: Editora Universidade de Brasília; São Paulo: Imprensa Oficial do Estado de São Paulo, 1999b. p. 526.

14 OLSSON, Giovanni. O poder político no espaço global: o protagonismo dos atores não estatais. In: OLIVEIRA, Odete Maria (Org.). Relações internacionais, direito e poder. cenários e protagonismos dos atores não estatais. Volume I. Ijuí: Ed. Unijuí, 2014. p. 133-178. p. 147. 
presídios, por exemplo, e consiste no único ente ao qual é permitido o uso da violência legítima nesse papel.

No que se refere ao uso do poder estatal tornando a violência legítima, Arendt ${ }^{15}$ aponta que a violência é a mais forte manifestação de poder e, sendo um Estado o representante do seu povo, sua violência passa a ser considerada "legítima".

Cabe notar que, na concepção de Arendt, ${ }^{16}$ entretanto, poder é diferente de violência. Contudo, comumente, os conceitos são tidos como semelhantes pela associação feita de poder em relação aos atos de mando e obediência, mas a violência é apenas uma das formas de exercício do poder, normalmente utilizada pelo governo dentro do Estado. Nas relações exteriores ou na proteção à sociedade, a violência deve ser a última opção a ser utilizada para que a soberania estatal permaneça intacta. 0 poder está no indivíduo que o delega a um terceiro para que prime pelo bem comum, e o exercício desse poder deveria cotidianamente dispensar o uso da violência, porque, ao legitimar o representante da sociedade para tomar as decisões em seus nomes, os indivíduos devem se submeter aos seus atos automaticamente.

A violência não é necessariamente um requisito do poder, porque, pelo contrário, para que o poder alcance os seus propósitos, ele deverá ser primeiramente legítimo, e não conquistado por coerção. Diz Arendt ${ }^{17}$ que “o poder não precisa de justificação, sendo inerente à própria existência das comunidades políticas; o que ele realmente precisa é de legitimidade. [...] A violência pode ser justificável, mas nunca será legítima".

Nessa linha e segundo essa autora, quando o Estado faz uso da violência para atingir o controle social, ele não está exercendo o poder propriamente, mas está apenas demostrando a sua soberania. A violência descaracteriza o poder, porque a obediência e a concordância conquistadas por meio do medo e da força física nunca serão consideradas um poder legítimo. ${ }^{18}$

Ao tratar do uso da violência legítima pelo Estado, as formas de violência mais próximas da realidade de todos os indivíduos que convivem em sociedade são a prisão e as penas privativas de liberdade e, para que se possa compreender por que esses meios de regulação social são classificados como violências cometidas

ARENDT, Hannah. Sobre a violência. Trad. Andre Duarte. 3. ed. Rio de Janeiro: Relume Dumará, 2001. p. 31.

ARENDT, Hannah. Sobre a violência. Trad. Andre Duarte. 3. ed. Rio de Janeiro: Relume Dumará, 2001. p. 38-40.

17 ARENDT, Hannah. Sobre a violência. Trad. Andre Duarte. 3. ed. Rio de Janeiro: Relume Dumará, 2001. p. 41.

18 ARENDT, Hannah. Sobre a violência. Trad. Andre Duarte. 3. ed. Rio de Janeiro: Relume Dumará, 2001. p. 41-44. 
pelo Estado, faz-se necessário entender a atual situação do sistema prisional e as mazelas que o cárcere causa ao apenado.

\section{A pena privativa de liberdade e as prisões}

A pena privativa de liberdade é o principal instrumento punitivo aplicado na atualidade. Quando foi instituída, a ela atribuía-se o poder de retirar da sociedade aqueles que não seguiam suas regras e também de reinseri-los, após determinado período, já reabilitados à convivência social.

A atual configuração da pena de reclusão mudou esse cenário, e muitos doutrinadores apontam a descrença na sua efetividade, embasada, principalmente, nas indignas privações que esta confere aos presos e nos altos índices de reincidência.

No século XIX, a pena de prisão tornou-se a principal forma de pena aplicada, por acreditar-se que esta seria a melhor forma de reabilitar o criminoso, mantendo-o segregado e sujeito a procedimentos especializados de ressocialização. Nos dias atuais, todavia, o quadro é bem diferente do idealizado no século XIX, e o posicionamento dominante é que o sistema prisional está em crise e, consequentemente, a própria pena privativa de liberdade como instrumento apropriado e efetivo para essa finalidade. Existem, ainda, vários estudos no sentido da impossibilidade total ou parcial de a prisão surtir algum efeito reformador em relação aos reclusos. ${ }^{19}$

A pena de reclusão, por ter se tornado apenas uma forma evoluída das penas corporais (visto que detém o corpo e a mente dos reclusos), não pode mais ser considerada idônea para cumprir os dois objetivos destinados à punição: a prevenção criminal e a prevenção especial. ${ }^{20}$

Segundo Thompson, ${ }^{21}$ para a pena são atribuídos os propósitos de: retribuição do mal causado, prevenção geral e especial, e regeneração do preso, objetivos ratificados e institucionalizados pela Lei de Execução Penal brasileira. Esses objetivos seriam alcançados através da detenção do preso e da aplicação de rigorosa disciplina. Porém, para o autor, os meios são mais valorizados do que os fins, causando uma distorção na finalidade punitiva e tornando prioridades a segurança e a disciplina, e não propriamente a prevenção e a ressocialização.

19 BITENCOURT, César Roberto. Falência da pena de prisão: causas e alternativas. 2. ed. São Paulo: Saraiva, 2001. p. 154.

20 FERRAJOLI, Luigi. Direito e razão: teoria do garantismo jurídico penal. 2. ed. ver. e ampl. Vários tradutores e colaboradores. São Paulo: Editora Revista do Tribunais, 2006. p. 378-379.

21 THOMPSON, Augusto. A questão penitenciária. Rio de Janeiro: Forense, 2002. p. 3-8. 
Por sua vez, a ineficácia da pena privativa de liberdade decorreria basicamente da impossibilidade de ressocializar o preso com o seu afastamento da sociedade, ou seja, do corpo social ao qual se pretende reinseri-lo e das condições materiais e humanas em que é realizada a execução, sem níveis suficientes para reabilitar o preso. ${ }^{22}$

Para Bitencourt, ${ }^{23}$ a crise vivenciada pelo sistema prisional é consequência da pouca importância dispensada ao assunto pela sociedade em geral e também pelos governantes, o que gera a necessidade de uma reforma, em certos momentos, mais ou menos radical, na busca pelo resgate de seu principal objetivo, que é a reabilitação do recluso.

Para Karam, ${ }^{24}$ deve-se enfrentar o paradoxo, presente mesmo nos Estados democráticos, de um sistema penal que tem como ponto central o exercício do poder punitivo por meio da restrição de um direito fundamental: a liberdade. Enquanto não for possível extinguir o cerceamento da liberdade, esse poder tem de ser extremamente controlado, sendo aplicado como uma exceção, apenas em último caso e limitado pelos direitos humanos dos detentos: "A subsistência da prisão, seja como pena, seja como medida de natureza processual demonstra o quanto ainda é preciso avançar na construção de um mundo em que a liberdade e os demais direitos fundamentais de todos os indivíduos sejam efetivamente concretizados e usufruídos".

Um dos principais motivos apontados para a falência da pena privativa de liberdade é o efeito criminógeno que ela causa: “Considera-se que a prisão, em vez de frear a delinquência, parece estimulá-la, convertendo-se em instrumento que oportuniza toda espécie de desumanidade. Não traz nenhum benefício ao apenado; ao contrário, possibilita toda sorte de vícios e degradações". ${ }^{25}$

Zaffaroni e Perangeli ${ }^{26}$ demostram a crise pela qual passa a pena privativa de liberdade, visto que, mesmo que cumpra uma função preventiva, sempre será utilizada para cumprir uma adicional função simbólica. Para isso, utilizase de um homem "como instrumento para sua simbolização, o usa como um meio e não como um fim em si, 'coisifica' um homem, ou, por outras palavras,

22 BITENCOURT, César Roberto. Falência da pena de prisão: causas e alternativas. 2. ed. São Paulo: Saraiva, 2001. p. 154-155.

23 BITENCOURT, César Roberto. Falência da pena de prisão: causas e alternativas. 2. ed. São Paulo: Saraiva, 2001. p. 157.

24 KARAM, Maria Lúcia. A privação da liberdade: o violento, danoso, doloroso e inútil sofrimento da pena. v. 7. Rio de Janeiro: Lúmen Júris, 2009. p. VIIIIX.

25 BITENCOURT, César Roberto. Falência da pena de prisão: causas e alternativas. 2. ed. São Paulo: Saraiva, 2001. p. 157.

26 ZAFFARONI, Eugenio Raúl; PIERANGELI, José Henrique. Manual de direito penal brasileiro. v. 1, parte geral. 6 ed. rev. e atual. São Paulo: Revista dos Tribunais, 2006. p. 96. 
desconhece-lhe abertamente o caráter de pessoa, como o que viola o princípio fundamental em que se assentam os Direitos Humanos".

A prisão, em suas atuais condições degradantes, pode apresentar graves consequências à saúde dos presos. Em se tratando de disciplina, a forma como é aplicada tende a aumentar as tendências delitivas dos reclusos e, ainda, a segregação por um longo período acaba por desadaptar o segregado ao meio social, tornando, ao final, ainda mais difícil sua reabilitação. ${ }^{27}$

De forma sintética, Oliveira ${ }^{28}$ apresenta as principais privações ocasionadas pela pena privativa de liberdade: (a) a privação de liberdade, que gera o desligamento da família, do lar e da convivência social; (b) a privação dos bens, visto que não é permitida a manutenção de objetos pessoais dentro das celas, resultando na perda total de identidade; (c) a privação da autonomia, pela obrigação de cumprimento das regras impostas pela administração prisional e a consequente impossibilidade de direito à escolha por parte do recluso; (d) a privação de segurança, gerada pela prática corriqueira de violência e ameaças, entre outras ofensas, visto a impossibilidade de defesa; (e) a privação de relações sexuais, pela impossibilidade do exercício do heterossexualismo; e (f) a privação de condições dignas de sobrevivência, ocasionada por todos os fatores já expressos, mas principalmente pela superlotação carcerária, que é decorrente de um número de presos muito superior ao número de vagas.

No mesmo sentido, Foucault ${ }^{29}$ já verificava que as penas corporais se baseavam no suplício do corpo, amputações, esquartejamentos e marcas de ferro, enquanto as punições morais se davam através da exposição, da confissão em praça pública e da agressão física em meio à sociedade. Essas penas, de forma velada, ainda hoje estão presentes na nossa sociedade.

Thompson, ${ }^{30}$ a seu turno, traz à tona um relevante questionamento: como é possivel reeducar alguém para viver em sociedade através do confinamento, ou seja, como pode ser esperar que aquele que se adéque aos padrões da prisão possa ser considerado como readaptado à convivência em liberdade? Muito além da irracionalidade em se esperar a ressocialização de um indivíduo retirando-o do convívio social, o grande erro está em achar que as condições que a ele são impostas no período de reclusão, como foi citado acima, podem regenerar alguém.

BITENCOURT, César Roberto. Falência da pena de prisão: causas e alternativas. 2. ed. São Paulo: Saraiva, 2001. p. 157. p. 159-159.

28 OLIVEIRA, Odete Maria de. Prisão: um paradoxo social. 3. ed. atual. e rev. Florianópolis: UFSC, 2003. p. 78-94.

29 FOUCAULT, Michael. Vigiar e punir. Trad. Raquel Ramalhete. 25. ed. Petrópolis: Vozes, 2002. p. 12.

30 THOMPSON, Augusto. A questão penitenciária. Rio de Janeiro: Forense, 2002. p. 11-13. 
Muito pelo contrário: a prisão nesse formato só pode gerar um comportamento antissocial ainda maior.

A pena de reclusão, imposta nas condições citadas acima, deve ser considerada como um abuso do poder punitivo por parte do Estado, considerandose penas cruéis e tratamento desumano. ${ }^{31}$

O ponto fundamental, porém, é que a pena privativa de liberdade não tem se mostrado um instrumento eficiente na repressão da criminalidade, prevenção da violência e nem para a ressocialização do condenado. ${ }^{32}$

Se a pena privativa de liberdade é um dos principais meios utilizados pelo Estado para a realização do controle social, e a sua imposição traz malefícios tão profundos aos indivíduos, impossibilitando, na maioria das vezes, a sua ressocialização e os mantendo na seara criminal, será que as condições às quais os indivíduos são submetidos são uma violência em seu sentido mais cruel? Como se pode entender a execução do poder estatal como legítimo? Seria essa uma forma de "violência aceitável"?

Visando trazer mais elementos elucidativos sobre o sistema penal e evidenciar ainda mais a descrença e a impossibilidade de efetividade da pena privativa de liberdade, apresentam-se brevemente a seguir teorias defendidas por duas grandes linhas de estudiosos do tema que propõem duas visões distintas do sistema penal: hipertrofiado e mais punitivo, de um lado, e abolicionista ou minimalista, de outro.

\section{Abolicionismo penal e minimalismo versus direito penal máximo e direito penal do inimigo}

Visando contextualizar as teorias em questão, apresenta-se um breve resgate conceitual dos discursos penais atuais que atuam em duas vertentes: uma em direção à minimização da aplicação do direito penal ou até mesmo sua exclusão por completo, e outra pela maximização da severidade das penas e hipertrofia do sistema.

31 KARAM, Maria Lúcia. A privação da liberdade: o violento, danoso, doloroso e inútil sofrimento da pena. Vol. 7. Rio de Janeiro: Lúmen Júris, 2009. p. 21.

32 CAMPOS, Teresinha Borges. Das penas privativas de liberdade às penas alternativas. São Paulo: Almedina Brasil, 2010. p. 262. 
Em primeiro lugar, o abolicionismo defende a supressão da pena e, neste caminho, quem sabe também até do direito penal, porém sem pleitear a abolição total do controle social pelo Estado. ${ }^{33}$

Ferrajoli ${ }^{34}$ apresenta as teorias abolicionistas como aquelas que não admitem que os objetivos da pena possam justificar as aflições que o direito penal causa, considerando vantajosa a abolição das sanções e, consequentemente, "a sua substituição por meios pedagógicos ou instrumentos de controle de tipo informal e imediatamente social".

Dessa feita, constata-se que o abolicionismo penal tem por objetivo a eliminação do sistema penal existente, porém não almeja a abolição total do controle social, mas, sim, a construção de um novo sistema de controle, no qual os conflitos sociais seriam resolvidos por outras áreas do direito.

Nesse sentido, Baratta ${ }^{35}$ apresenta como críticas ao direito penal que este defende somente os bens essenciais e, quando pune esses crimes, o faz de forma desigual e de modo fragmentário; que a lei penal não se aplica de forma igual para todos, sendo o status de criminoso distribuído de modo desigual, e "que o grau efetivo de tutela e a distribuição do status de criminoso é independente da danosidade social das ações e da gravidade das infrações à lei, no sentido de que estas não constituem a variável principal da reação criminalizante e da sua intensidade".

Para Andrade, ${ }^{36}$ o valor considerável de cifras negras demonstra que a criminalidade real é superior à detectada pelo sistema, podendo constatar-se que a infração da lei penal faz parte do comportamento da maioria da sociedade, porém esta criminalidade é distribuída seletivamente: "Esta seletividade do sistema penal (maior criminalidade, especialmente das classes altas, regularmente impune - minoria pobre regularmente criminalizada) se deve, fundamentalmente, a duas variações estruturais". São elas: a insuficiência do sistema penal frente à abrangência deste sistema; e a problemática que seria criminalizar efetivamente todas as condutas, visto que não restaria nem um indivíduo que não fosse considerado como criminoso.

33 FERRAJOLI, Luigi. Direito e razão: teoria do garantismo jurídico penal. 2. ed. rev. e ampl. Vários tradutores e colaboradores. São Paulo: Editora Revista dos Tribunais, 2006. p. 232.

34 FERRAJOLI, Luigi. Direito e razão: teoria do garantismo jurídico penal. 2. ed. rev. e ampl. Vários tradutores e colaboradores. São Paulo: Editora Revista dos Tribunais, 2006. p. 231.

35 BARATTA, Alessandro. Criminologia crítica e crítica do direito penal: introdução à sociologia do direito penal. Rio de Janeiro: Freitas Bastos, 1999. p. 162.

36 ANDRADE, Vera Regina Pereira de. Sistema pena máximo X cidadania mínima: códigos da violência na era da globalização. Porto Alegre: Livraria do Advogado, 2003. p. 50-51. 
Complementando essa concepção, Andrade ${ }^{37}$ aponta que "a criminalidade se revela, principalmente, como um status atribuído a determinados indivíduos mediante um duplo processo: a 'definição' legal de crime, que atribui à conduta ao caráter criminal, e a 'seleção' que etiqueta e estigmatiza um autor como criminoso entre todos aqueles que praticam tais condutas".

Para Pinho, ${ }^{38}$ o caminho sugerido pelo abolicionismo é a eliminação total do sistema penal e a busca por métodos alternativos para a resolução de conflitos, podendo ser métodos aplicados pela própria sociedade ou pelo Estado enquanto mediador na busca da solução.

Greco, ${ }^{39} \mathrm{em}$ seus escritos, defende que, para a teoria abolicionista, a prisão é um instituto irracional, e sua utilização ofende de plano o princípio da dignidade humana. Nesse contexto, a teoria abolicionista apresenta soluções interessantes à resolução de conflitos; porém, a não aplicação do direito penal seria inviável para a manutenção da ordem social, visto a gama de crimes de cunho extremamente violento que muitas vezes causam danos irreparáveis e exigem uma reposta por parte do Estado, no intuito de proteger a sociedade e manter sua harmonia.

Seguindo a mesma vertente, apresenta-se a teoria minimalista, que "apregoa, em síntese, ser a finalidade do Direito Penal a proteção tão somente dos bens necessários e vitais ao convívio em sociedade. Aqueles bens que, em decorrência de sua importância, não poderão ser somente protegidos pelos demais ramos do ordenamento jurídico". ${ }^{40}$

A teoria do direito penal mínimo representa a garantia das liberdades dos cidadãos em nível máximo em oposição ao poder punitivo, bem como um parâmetro de racionalidade e certeza das sentenças aplicadas com o objetivo de evitar os erros de condenação. ${ }^{41}$

Para a aplicação do direito penal mínimo, se faz necessária a observância de alguns princípios: “a) intervenção mínima; b) lesividade; c) adequação social; d) insignificância; e) individualização da pena; f) proporcionalidade; g) responsabilidade pessoal; h) limitação das penas; i) culpabilidade; e j) legalidade". ${ }^{42}$

37 ANDRADE, Vera Regina Pereira de. Sistema pena máximo X cidadania mínima: códigos da violência na era da globalização. Porto Alegre: Livraria do Advogado, 2003. p. 41.

38 PINHO, Ana Cláudia Bastos de. Direito penal e estado democrático de direito: uma abordagem a partir do garantismo de Luigi Ferrajoli. Rio de Janeiro: Lúmen Júris, 2006. p. 17.

39 GRECO, Rogério. Direito penal do equilíbrio: uma visão minimalista do direito penal. 2. ed. Niterói: Impetus, 2006. p. 13-14.

40 GRECO, Rogério. Direito penal do equilíbrio: uma visão minimalista do direito penal. 2. ed. Niterói: Impetus, 2006. p. 30.

41 FERRAJOLI, Luigi. Direito e razão: teoria do garantismo jurídico penal. 2. ed. rev. e ampl. Vários tradutores e colaboradores. São Paulo: Editora Revista dos Tribunais, 2006. p. 102.

42 GRECO, Rogério. Direito penal do equilíbrio: uma visão minimalista do direito penal. 2. ed. Niterói: Impetus, 2006. p. 30 . 
Assim, o princípio da intervenção mínima tem por objetivo principal a proteção dos bens jurídicos mais importantes, orientando a criação ou extinção dos tipos penais; o princípio da lesividade tem a tarefa de verificar a lesividade da ação a terceiros, ou seja, tem de ser uma conduta antissocial que atinja a esfera de terceiros; o princípio da adequação social tem o intuito de orientar a tipificação penal conforme a evolução dos conceitos morais da sociedade; já o princípio da insignificância segue no mesmo sentido do princípio da intervenção mínima, no qual cabe delimitar quais bens são significantemente importantes para serem protegidos pelo direito penal. ${ }^{43}$

Quanto ao princípio da individualização da pena, sua função é determinar o grau de importância de cada bem jurídico protegido e, em consonância com esta avaliação, estabelecer a pena a ser aplicada; seguindo na mesma direção, o princípio da proporcionalidade tem a função de garantir que a pena será proporcional ao mal cometido; já o princípio da responsabilidade tem o objetivo de garantir que a pena não passará da pessoal do condenado, conforme já descrito em nossa Constituição Federal. ${ }^{44}$

Também previsto constitucionalmente, o princípio da limitação das penas tem por objeto a não permissão de penas de morte, perpétua, de trabalhos forçados, de banimento e cruéis; quanto ao princípio da culpabilidade, cabe averiguar se a conduta realizada é punível ou não em razão das circunstâncias que geraram a ação e, por último, o princípio da legalidade tem a função de fiscalizar se os atos jurídicos estão de acordo com a legislação, em sentido formal e material. ${ }^{45}$

Por sua vez e em contraponto à teoria do abolicionismo e do direito penal mínimo estão as teorias do direito penal máximo e do direito penal do inimigo, as quais defendem um direito penal mais severo e hipertrofiado.

O direito penal máximo é resultado do clamor social proveniente de situações que causam revolta, muitas vezes alimentadas pelo sensacionalismo promovido pela vítima. Essa teoria tem como uma de suas vertentes o movimento denominado Tolerância Zero, no qual a prática estabelecida é a ampliação da tipificação penal com o objetivo de tutelar todo e qualquer bem jurídico, transformando em crime qualquer prática antissocial que possa atingir esses bens. ${ }^{46}$

43 GRECO, Rogério. Direito penal do equilíbrio: uma visão minimalista do direito penal. 2. ed. Niterói: Impetus, 2006. p. 30-32.

44 GRECO, Rogério. Direito penal do equilíbrio: uma visão minimalista do direito penal. 2. ed. Niterói: Impetus, 2006. p. 30-34.

45 GRECO, Rogério. Direito penal do equilíbrio: uma visão minimalista do direito penal. 2. ed. Niterói: Impetus, 2006. p. 34-35.

46 GRECO, Rogério. Direito penal do equilíbrio: uma visão minimalista do direito penal. 2. ed. Niterói: Impetus, 2006. p. 16-18. 
Para a teoria do direito penal máximo, o sistema penal é incondicionado e ilimitado, resultando em punições mais severas, incertas e imprevisíveis; ou seja, sem parâmetros de análise, o poder punitivo se torna incontrolável e ilimitado. ${ }^{47}$

Seguindo a mesma vertente do direito penal máximo, que é uma teoria decorrente do movimento "Lei e Ordem", encontra-se a teoria do "direito penal do inimigo".

Para Jakobs, ${ }^{48}$ existem dois tipos de direito: o direito penal do cidadão e o direito penal do inimigo. 0 direito penal do cidadão, de cunho garantista, tem como função a observância dos princípios fundamentais, enquanto o direito penal do inimigo não observa os princípios fundamentais em razão de considerar os cidadãos criminosos como inimigos do Estado.

A teoria do direito penal do inimigo, por sua vez, pressupõe o fato criminoso, ou seja, atua no sentido de previsão de conduta delitiva antes que esta ocorra, e não no sentido de tipificar a conduta apenas após sua ocorrência. Essa teoria apresenta ainda um aumento na quantidade das penas a serem aplicadas, bem como a diminuição das garantais processuais. ${ }^{49}$

Nesse sentido, Nucci ${ }^{50}$ aponta que a teoria do direito penal do inimigo tem por objetivo identificar quais indivíduos pertencentes à sociedade devem ser considerados como inimigos do Estado por sua capacidade de lesão e desestabilização deste. Seriam, por exemplo, considerados como inimigos do Estado os autores de crimes graves e de grandes proporções, não merecendo, assim, a tutela de garantias fundamentais por parte do Estado.

Desta feita, o abolicionismo aponta as falhas existentes no sistema penal atual, apresentando, como uma alternativa para resolução de conflitos, a aplicabilidade de outros ramos do direito com o objetivo de reparar o dano causado especificamente para a vítima. Contudo, sua aplicabilidade pura, que significaria na prática a não intervenção estatal e a eliminação por completo do direito penal, encontra restrições, visto o descontrole e anarquia em que poderia resultar.

Por sua vez, as teorias apresentadas pelo direito penal máximo e pelo direito penal do inimigo contribuem como elementos importantes ao debate, porém sua aplicação se torna inviável, visto a ofensa direita aos princípios fundamentais por parte do direito penal máximo, bem como a fragilidade apresentada pela teoria

47 FERRAJOLI, Luigi. Direito e razão: teoria do garantismo jurídico penal. 2a ed. rev. e ampl. Vários tradutores e colaboradores. São Paulo: Editora Revista dos Tribunais, 2006. p. 102.

48 JAKOBS, Günther; MELIA, Manuel Cancio. Direito penal do inimigo: noções e críticas. Tradução André Luís Callegari e Nereu José Giacomolli. Porto Alegre: Livraria dos Advogados, 2005. p. 21.

49 GRECO, Rogério. Direito penal do equilíbrio: uma visão minimalista do direito penal. 2. ed. Niterói: Impetus, 2006. p. 23-25.

$50 \mathrm{NUCCl}$, Guilherme de Souza. Manual de direito penal. 2. ed. São Paulo: Revista dos Tribunais, 2006. p. 364. 
do direito penal do inimigo totalmente desprovida de parâmetros de tipificação e movida por situações que despertam comoção social, em que praticamente todas as garantias processuais passam a ser relativizadas e aplicadas seletivamente.

Diante do exposto e no âmbito do debate neste estudo sobre o "poder sobre" por parte do Leviatã, parece mais seguro o caminho apresentado pela teoria do direito penal mínimo, visto que estabelece parâmetros de tipificação penal e de condenação baseados em garantias fundamentais constitucionais, não eximindo o Estado, porém, de seu dever de punição em detrimento da proteção social. Contudo, deve limitar sua ação para que não seja arbitrária e desmedida, tornando, assim, o seu poder de aplicação da violência legítima em um poder ilegítimo.

As teorias ora apresentadas tomam por base os altos índices de criminalidade e a incapacidade do sistema penal em realizar uma persecução penal eficiente, resultando nas conhecidas cifras negras da criminalidade, assim como nas indiscutíveis mazelas que o cárcere causa aos indivíduos e os baixos índices de ressocialização. Esse cenário representa o pano de fundo da aplicabilidade da violência legítima estatal, sua ineficiência e os profundos danos causados ao indivíduo, a merecerem debate atento e urgente.

Após este breve relato acerca das teorias do abolicionismo, direito penal mínimo, direito penal máximo e direito penal do inimigo, faz-se crucial o estudo sobre a situação vivenciada pelo sistema prisional brasileiro particularmente quanto à seletividade inerente a esse sistema, que remete para a percepção de um sistema estatal de aplicação de violência especialmente ilegítima.

\section{0 sistema prisional brasileiro e a seletividade penal}

O sistema penitenciário brasileiro, hoje regido pela Lei de Execução Penal, regulamenta o jus puniendi detido pelo Estado. $O$ direito de punir é de competência estatal pela expressão de sua soberania e supremacia e, em consequência, é impossível que o Estado delegue a outrem a obrigação de punir. Assim, à vítima, em algumas hipóteses, cabe apenas a prerrogativa de provocar o Judiciário e dar início ao processo para que, após o trânsito em julgado, possa, então, o Estado exercer de forma efetiva seu direito de punir. Sendo a pretensão punitiva exclusiva do Estado, esta é prevista de forma abstrata, e sua efetivação ocorre apenas quando da comprovação de um fato classificado como crime. Para tanto, 
quando constatada a prática delitiva, o direito sai da esfera abstrata e consolidase através da aplicação de uma pena ao autor do crime. ${ }^{51}$

São puníveis as práticas definidas como típicas e ilícitas descritas pelo Código Penal brasileiro e, para que se chegue até o momento da aplicação da pena, é necessário percorrer um longo caminho denominado processo penal, objetivando que o Estado não cometa erros tanto quanto ao destinatário da punição e sua graduação, como quanto às garantias do cidadão nesse itinerário. Com o fim do processo penal e trânsito em julgado da sentença penal condenatória, inicia-se a fase denominada execução penal, com a aplicação da punição em concreto conforme determinado pela sentença condenatória proferida pelo devido processo legal e em atenção às garantias constitucionais.

Para Capez, ${ }^{52}$ a execução penal é o meio pelo qual o Estado efetiva sua pretensão punitiva ou a aplicação prática do direito de punir. A punição a ser imputada tem caráter restritivo, porque, partindo do pressuposto da privação de um bem jurídico do autor de um fato criminoso, objetiva o Estado a retribuir ao punido o mal que este causou à sociedade e, consequentemente, fazer com que aquele que for penalizado se sinta coagido a não delinquir novamente, buscando como resultado a reinserção social do indivíduo em condições de convivência pacífica.

Carvalho ${ }^{53}$ define o direito penitenciário como a legislação que tem por objeto a regulamentação do sistema carcerário, instituindo normas que disciplinarão a conduta do preso, e a administração dos presídios, utilizando-se dessa capacidade de instituir normas que regulamentem o cumprimento de pena com fundamento na ordem e disciplina, mas que acaba por restringir os direitos garantidos ao apenado.

O direito brasileiro, objetivando limitar o poder da administração carcerária, amenizar a violação aos direitos do condenado e organizar o sistema carcerário, editou a Lei de Execução Penal. Essa legislação trouxe grandes inovações na forma em que se dava a execução da sentença que condenava um indivíduo a uma pena privativa de liberdade.

A finalidade da execução penal está expressa no artigo 1ํ da Lei de Execução Penal ${ }^{54}$ e realiza-se em duas vertentes: (a) "efetivar as disposições da sentença"; e (b) "proporcionar condições para a harmônica integração social do condenado".

\footnotetext{
CAPEZ, Fernando. Execução penal. 12. ed. São Paulo: Damásio de Jesus, 2006. p. 15-16.

CAPEZ, Fernando. Execução penal. 12. ed. São Paulo: Damásio de Jesus, 2006. p. 16-17.

CARVALHO, Saulo de. Pena e garantias. Rio de Janeiro: Lúmen Júris, 2003. p. 168.

54 Brasil. Lei de Execução Penal. Disponível em: <http://www.planalto.gov.br/ccivil_03/leis/L7210.htm>. Acesso em: 30 jun. 2017.
} 
A execução penal embasa-se na teoria mista da finalidade da pena, através da qual, além de cumprir-se o caráter punitivo da pena, retribuindo o mal causado pelo criminoso, ainda tem por objetivo, através da punição, inibir a prática criminal por gerar no preso a consciência de seus erros e possibilitar assim sua posterior reinserção social. ${ }^{55}$

Para cumprir o objetivo-fim da execução penal, ou seja, a reinserção do preso na sociedade, a Lei de Execução Penal determina a instituição e o cumprimento de vários procedimentos das penitenciárias, descritos principalmente nos artigos em que se trata dos direitos e deveres reservados aos presos.

0 art. 3ㅇ da Lei de Execução Penal, ${ }^{56}$ por sua vez, estabelece de forma clara que ao preso não será restrito nenhum direito além daqueles sobrevenientes da condenação. Desta feita, cabe analisar primeiramente os direitos individuais fundamentais destinados aos reclusos e protegidos pela Constituição Federal como cláusulas pétreas.

0 art. 5으, inciso III, da Constituição da República Federativa do Brasil| ${ }^{57}$ publicada em 1988 determina claramente que ninguém será submetido à tortura ou tratamento desumano. Esse princípio constitucional tem por finalidade a proteção à integridade física do indivíduo, tutela garantida a todo e qualquer indivíduo brasileiro, sem nenhuma distinção, conforme estabelece o próprio caput do artigo já citado, protegendo, em consequência, também aqueles que se encontram sob a tutela estatal em virtude de fato delitivo.

Ao presidiário, ainda é garantido pela Carta Magna ${ }^{58}$ (inciso XLVIII do artigo 5) o cumprimento da pena em estabelecimento adequado às condições de cada preso, tendo como parâmetro de análise a natureza do delito, a idade e o sexo do condenado. Especificamente para as detentas, é assegurada (inciso $L$ do artigo 5) a permanência de seus filhos junto a elas durante o período de amamentação.

De forma específica, a Lei de Execução Penal ${ }^{59}$ também garante ao recluso várias prerrogativas objetivando atingir sua reinserção social, como previstas nos artigos 10 a 27 da referida lei, incluindo-se a assistência material, de saúde, jurídica, educacional, social e religiosa.

55 CAPEZ, Fernando. Execução penal. 12. ed. São Paulo: Damásio de Jesus, 2006. p. 19.

56 BRASIL. Lei de Execução Penal. Disponível em: <http://www.planalto.gov.br/ccivil_03/leis/L7210.htm>. Acesso em: 30 jun. 2017.

57 BRASIL. Constituição da República Federativa do Brasil. Disponível em: <http://www.planalto.gov.br/ ccivil_03/constituicao/constituicao.htm>. Acesso em: 30 jun. 2017.

58 BRASIL. Constituição da República Federativa do Brasil. Disponível em: <http://www.planalto.gov.br/ ccivil_03/constituicao/constituicao.htm>. Acesso em: 30 jun. 2017.

59 BRASIL. Lei de Execução Penal. Disponivel em: <http://www.planalto.gov.br/ccivil_03/leis/L7210.htm>. Acesso em: 30 jun. 2017. 
A prestação da assistência destinada aos presos, em suas mais diversas formas, é dever do Estado, e sua principal finalidade é a orientação do recluso para a reinserção social.

Diante dessa sucinta análise da Lei de Execução Penal, ficam evidentes as dúvidas sobre se os direitos dos presos previstos pela Lei de Execução Penal são realmente cumpridos, diante da real situação instaurada no sistema prisional brasileiro.

Como dito, os direitos instituídos aos presos têm por objetivo limitar o poder punitivo do Estado. Essa gama de direitos destinados aos reclusos é consequência de um movimento que entende ser a privação de liberdade uma medida extrema, que persiste por ainda não se ter encontrado um substituto e também pelo pouco interesse destinado à busca de alternativa. Como medida extrema, deve ser regulada intensivamente e tratada de forma excepcional..$^{60}$

O sistema prisional brasileiro, hoje, porém, apresenta-se como verdadeiro depósito de pessoas, no qual os indivíduos que transgrediram a lei e que, por isso, devem ser afastados da sociedade são mantidos em condições precárias e usualmente indignas. A população carcerária excede de forma estrondosa o espaço físico das prisões, negando-se aos presos a oportunidade de efetivar seus direitos e deveres previstos pela Lei de Execução Penal, dificultando a fiscalização pelos agentes prisionais e gerando, assim, nos presos, o sentimento de revolta, bem como ânsia pela fuga desse lugar considerado, por muitos, um "inferno". Diante da calamidade em que se encontra o sistema prisional, é fundada a dúvida sobre se realmente esse sistema oportuniza ao recluso, em alguma medida, sua reintegração e ressocialização.

Para Delmanto Junior, ${ }^{61}$ a Lei de Execução Penal não vem sendo bem aplicada por falta de recursos no sistema prisional, e reitera que de nada adianta a realização adequada do processo penal para o condenado ser jogado em uma prisão dominada por grupos criminosos, na qual sua sobrevivência depende de sua aliança com um desses grupos. Com isso, estabelece-se um processo de recriminalização e aprofundamento de vínculos com o crime organizado, e não a reintegração social.

O sistema penitenciário brasileiro, para Rolim, ${ }^{62}$ encontra-se em crise, visto o agravamento de situações como os altos índices de reincidência, a superlotação

60 ZAFFARONI, Eugenio Raúl; PIERANGELI, José Henrique. Manual de direito penal brasileiro. v. 1, parte geral. 6. ed. rev. e atual. São Paulo: Revista dos Tribunais, 2006. p. 85.

61 DELMANTO JUNIOR, Roberto. 25 anos de lei de execução penal. Revista Brasileira de Ciências Criminais. São Paulo: Revista dos Tribunais, n. 201, p. 6, ago. 2009. p. 6.

62 ROLIM, Marcos. Prisão e ideologia: limites e possibilidades para a reforma prisional no Brasil. In: CARVALHO, Salo de (Org.). Crítica à execução penal. 2. ed. Rio de Janeiro: Lúmen Júris, 2007. p. 77-110. 
carcerária, o aumento da violência entre os presos, a prática de abusos, maustratos e tortura, falta de garantias mínimas, bem como o total desrespeito aos direitos humanos.

Na mesma linha, Ferrajoli ${ }^{63}$ sustenta que a prisão vai muito além da privação de determinado período de liberdade, porque é uma instituição “antiliberal, desigual, atípica, extralegal e extrajudicial, ao menos em parte, lesiva para a dignidade das pessoas, penosa e inutilmente aflitiva".

Corroborando com os outros autores, Thompson ${ }^{64}$ enfatiza que, até os dias de hoje, a prisão não logrou êxito na busca pela recuperação dos criminosos. Ele aponta como uma das justificativas mais apresentadas pela sociedade a falta de recursos para investimento estrutural, porém não concorda que somente o aumento de investimento em infraestrutura faça com que se possa reeducar os reclusos. Ele defende que, para que as penitenciárias possam realmente cumprir seu objetivo ressocializador, faz-se necessária uma análise sobre se os profissionais que trabalham com os presos possuem reais condições de exercer suas atividades com êxito e, em termos gerais, se algum país terá possibilidade de investir recursos suficientes para sua manutenção.

Diante dessa exposição, traça-se, de forma singela, o cenário do sistema prisional brasileiro, constatando-se sua ineficiência, fragilidade e inadequação física e operacional, o que, sem dúvida, interfere no cumprimento de sua função ressocializadora, porque não se pode esperar que um indivíduo que infringiu a lei e foi condenado à prisão e é submetido a tais circunstâncias de sobrevivência possa retornar para a sociedade recuperado, consciente de seu erro e disposto a não delinquir novamente. No fundo, a crise enfrentada pelo sistema prisional incorpora-se na crise pela qual passa a pena privativa de liberdade, o que gera a descrença nesse instituto e também o sentimento de insegurança presente na sociedade atual.

Aliado a isso, muitos estudos demostram que o sistema penal brasileiro é seletivo, em razão de sua legislação e sua prática, quanto ao tipo de conduta criminalizada e ao seu público-alvo.

O primeiro ponto é exemplificado pelas maiores penas atribuídas a crimes patrimoniais, em detrimento de outros valores e bens tutelados, inclusive o interesse público e a administração pública, como os crimes de colarinho branco que ficam escondidos dos olhos da sociedade, ampliando ainda mais as cifras negras da criminalidade.

63 FERRAJOLI, Luigi. Direito e razão: teoria do garantismo jurídico penal. 2. ed. ver. e ampl. Vários tradutores e colaboradores. São Paulo: Editora Revista dos Tribunais, 2006. p. 379-380.

64 THOMPSON, Augusto. A questão penitenciária. Rio de Janeiro: Forense, 2002. p. 15-18. 
O segundo aspecto consolida-se pela forma extremamente abrangente como a legislação penal brasileira está posta e pela insuficiência estatal frente à necessidade de fiscalização de toda sua população. Em face disso, os indivíduos de menor instrução e os de renda mais baixa tornam-se os maiores e mais fáceis alvos do sistema penal, porquanto estes são presos e condenados mais facilmente que aqueles indivíduos que possuem recursos financeiros e intelectuais para perpetrar e esconder seus crimes e, ainda, caso sejam detectados, para se defenderem frente à justiça.

Para Baratta, ${ }^{65}$ o atual sistema penal tem como grandes problemas: a proteção apenas para os bens essenciais e, ainda assim, o faz de forma desigual; a desigualdade da aplicação penal entre os indivíduos; e a aplicação do status de criminoso e da tutela jurídica independente do dano causado à sociedade ou da gravidade da infração cometida.

Andrade ${ }^{66}$ aponta que a seletividade penal é consequência da "especificidade da infração e das conotações sociais dos autores para seleção desigual de pessoas de acordo com seus status social e não pela criminalização igualitária de condutas objetivas e subjetivamente consideradas em relação ao fato-crime". Assim, o sistema penal tem como público-alvo a parte pobre da população, mas não porque são mais propensos ao crime, mas, sim, porque são mais facilmente considerados como criminosos, perseguidos e punidos.

Nesse sentido, Gomes e Bianchini ${ }^{67}$ consideram que "para a prisão mandamos quase que exclusivamente 'os da última fileira social', reafirma-se a generalizada (e equivocada) concepção de que [...] crime é algo de 'raça bastarda', da classe degradada, dos miseráveis, dos viciados e marginalizados".

Assim, a criminalidade é distribuída de forma seletiva, imunizando as classes altas e criminalizando as classes baixas. Consequentemente, o que se vê é o predomínio dos pobres nas prisões e também nas estatísticas. $E$ isso não se dá por acaso, porque é uma consequência do sistema penal que destaca a importância dos estereótipos dos autores e das vítimas, associada ao senso comum sobre a criminalidade. ${ }^{68}$

Outra circunstância que facilita a maior criminalização das classes mais baixas é a diferença entre os crimes cometidos, em maior ou menor escala, pelas

65 BARATTA, Alessandro. Criminologia crítica e crítica do direito penal: introdução à sociologia do direito penal. Rio de Janeiro: Freitas Bastos, 1999. p. 162.

66 ANDRADE, Vera Regina Pereira de. Sistema pena máximo X cidadania mínima: códigos da violência na era da globalização. Porto Alegre: Livraria do Advogado, 2003. p. 51-54.

67 GOMES, Luiz Flávio; BIANCHINI, Alice. O direito penal na era da globalização. São Paulo: Revista dos Tribunais, 2002. p. 157-158.

68 ANDRADE, Vera Regina Pereira de. A ilusão de segurança jurídica: do controle da violência à violência do controle penal. Porto Alegre: Livraria do Advogado, 1997. p. 268-269. 
classes baixas e classes altas. Normalmente, os crimes cometidos pelas classes pobres são crimes contra o patrimônio, como furto e roubo ou contra a vida, como homicídio; já nas classes altas, os crimes mais comuns são os crimes tributários, dificilmente constatados materialmente, e os crimes em âmbito público, como corrupção e desvio de verbas, os quais, como já apontado, possuem em geral também penas mais brandas.

Nesse sentido, Baratta ${ }^{69}$ aponta que é maior o percentual da população de baixa renda entre os apenados (subproletariado e grupos marginais). Isso se deve às dificuldades de acesso ao mercado de trabalho, bem como às baixas remunerações recebidas pela falta de qualificação profissional e às dificuldades de acesso à formação escolar. Ele destaca que as circunstâncias que, "na criminologia positivista e em boa parte da criminologia liberal contemporânea são indicados como as causas da criminalidade, revelam ser, antes, conotações sobre a base das quais o status de criminoso é atribuído".

Seguindo a mesma frente, Campos $^{70}$ argumenta que a população carcerária no Brasil é constituída basicamente por jovens, pobres e com baixo nível de escolaridade, e que, devido à pobreza, o condenado e seus familiares não possuem influência política, traduzindo-se em raras chances de obtenção de auxílio contra os abusos sofridos.

Com base nos apontamentos feitos, constata-se que o sistema penal brasileiro enfrenta dificuldade de cumprir sua função, e a legislação penal considerada abrangente acaba por impossibilitar ao Estado o seu efetivo cumprimento e, assim, tendem a ser criminalizados aqueles indivíduos provenientes de classes sociais mais baixas por sua própria condição social e também pelos tipos de delitos cometidos.

Essa seletividade penal interfere diretamente dentro do sistema prisional, tanto na composição da população carcerária quanto na busca pela reabilitação dos reclusos. Assim, esses elementos apontam que o sistema penal brasileiro é seletivo e, consequentemente, torna-se a expressão da desigualdade social e a caracterização da impunidade aos poderosos e abastados, e, mais do que isso, embasam a constatação da violência causada pelo Estado aos reclusos, no uso do seu poder até então pretensamente legítimo.

69 BARATTA, Alessandro. Criminologia crítica e crítica do direito penal: introdução à sociologia do direito penal. Rio de Janeiro: Freitas Bastos, 1999. p. 165.

70 CAMPOS, Teresinha Borges. Das penas privativas de liberdade às penas alternativas. São Paulo: Almedina Brasil, 2010. p. 262. 


\section{Considerações finais}

O Estado foi concebido pela necessidade de regular a convivência entre os indivíduos, e não para disseminar a violência. Assim, de um acordo entre homens que delegaram seu poder para o Leviatã a fim de receberem proteção, ordem e atingir o bem comum, surge o Estado.

$\mathrm{O}$ poder tem em seu âmago a imposição de uma vontade sobre outra e, na atualidade, tem se reconfigurado para muito além da sua forma clássica de "poder sobre" exercido pelo subjugo, principalmente pelo Estado em seus atos de império, mas está também nas mãos da sociedade civil organizada como "poder para" como uma força produtiva. Todavia, o que interessa especialmente neste trabalho é o uso do "poder sobre" por parte do Estado e a legitimação do uso da violência.

O Estado desenvolve seu poder a partir da utilização de instituições jurídicas, administrativas, políticas, econômicas e policiais. A imposição do poder estatal ocorre pela determinação das leis e exigência de seu cumprimento, pela punição daqueles que as descumprirem, pela realização da guerra, entre outros. Visando ao controle social, o Estado faz uso de diversos mecanismos, como tribunais, corporação policial, presídios, exército e poder bélico, sendo o único ente ao qual é permitido o uso da violência de forma legítima.

A principal forma de violência legítima exercida pelo Estado, por sua vez, é a aplicação da pena privativa de liberdade e submissão dos condenados ao sistema prisional. Esse sistema sofre muitas críticas fundamentadas nas principais privações ocasionadas pela pena privativa de liberdade, podendo-se citar o desligamento familiar e da convivência social, a privação dos bens, a privação de segurança em razão da violência existente dentro dos presídios, a privação de condições dignas de sobrevivência pela falta de condições de higiene e saúde e principalmente pela superlotação carcerária. Todos esses fatores demonstram a crise do sistema prisional e sua consequente falência já há muito tempo anunciada, resultado de um modelo penal falho e seletivo, como ficou muito claro no desenvolvimento deste trabalho.

A pena de reclusão, imposta nessas condições, deve ser considerada como um abuso do poder punitivo do Estado, podendo-se equiparar a um tratamento desumano.

O sistema penal apresenta ainda outro grande problema, a sua seletividade, que se dá em razão da proteção primordial dos bens essenciais e a desigualdade da aplicação penal entre os indivíduos. Assim, o sistema penal acaba por se impor, principalmente, sobre a parte pobre da população, mas não porque são 
mais propensos ao crime, mas, sim, porque são mais facilmente considerados como criminosos, perseguidos e punidos.

O Estado, ao selecionar uma parcela específica dos indivíduos para serem criminalizados, ao permitir que crimes como de colarinho branco tenham penalidades mais amenas e ao submeter um indivíduo a condições desumanas como tortura, superlotação, ausência de assistência médica (causando mazelas físicas e mentais ao apenado, até irremediáveis), ultrapassa os parâmetros da violência permitida para a garantia da segurança pública e acaba por desenvolver uma violência ilegítima, mas que é protegida pela sua soberania e supremacia.

Tal constatação é consequência do descompasso existente entre a finalidade da pena, como forma de violência legítima, e a realidade do sistema prisional, tornando desumana a violência praticada pelo Estado e, por certo, de elevada inefetividade sistêmica.

The State power using legitimate violence: a glance at Brazilian prisional system and its (in) effectiveness

\begin{abstract}
The article aims to understand how the State, wielding its sovereign power, uses legitimate violence, especially on application of restrictive of freedom penalty and the prison system. In order to do that, it's necessary to comprehend the modern concepts of power, the constitution of the State, the violence and its relation to the power understood as legitimate, as theories that advocate a minimum and maximum application of criminal law, and so the crisis in the restrictive of freedom penalty and the prison system. For the development of the article, the methodology is the bibliographic revision and the deductive method.
\end{abstract}

Keywords: Power. Nation-State. Violence. Prison.

Summary: 1 Initial considerations - 2 Power as an evolving category - $\mathbf{3}$ The Nation-State and legitimate violence $\mathbf{- 4}$ Custodial sentence and prisons $\mathbf{- 5}$ Crinimal abolitionism and minimalism versus maximum criminal law and enemies criminal law $-\mathbf{6}$ Brazilian prison system and criminal selectivity $-\mathbf{7}$ Final considerations - References

\title{
Referências
}

ANDRADE, Vera Regina Pereira de. A ilusão de segurança jurídica: do controle da violência à violência do controle penal. Porto Alegre: Livraria do Advogado, 1997.

ANDRADE, Vera Regina Pereira de. Sistema pena máximo X cidadania mínima: códigos da violência na era da globalização. Porto Alegre: Livraria do Advogado, 2003.

ARENDT, Hannah. Sobre a violência. Trad. Andre Duarte. 3. ed. Rio de Janeiro: Relume Dumará, 2001. 
BARATTA, Alessandro. Criminologia crítica e crítica do direito penal: introdução à sociologia do direito penal. Rio de Janeiro: Freitas Bastos, 1999.

BITENCOURT, César Roberto. Falência da pena de prisão: causas e alternativas. 2. ed. São Paulo: Saraiva, 2001.

BOURDIEU, Pierre. Language and symbolic power. Edited and introduced by John B. Thompson. Translated by Gino Raymond and Matthew Adams. Oxford: Polity Press, 1991.

BRASIL. Lei de Execução Penal. Disponível em: <http://www.planalto.gov.br/ccivil_03/leis/ L7210.htm>. Acesso em: 30 jun. 2017.

CAMPOS, Teresinha Borges. Das penas privativas de liberdade às penas alternativas. São Paulo: Almedina Brasil, 2010.

CARVAlHO, Saulo de. Pena e garantias. Rio de Janeiro: Lúmen Júris, 2003.

CAPEZ, Fernando. Execução penal. 12. ed. São Paulo: Damásio de Jesus, 2006.

DELMANTO JUNIOR, Roberto. 25 anos de lei de execução penal. Revista Brasileira de Ciências Criminais. São Paulo: Revista dos Tribunais, n. 201, p. 6, ago. 2009.

FERRAJOLI, Luigi. Direito e razão: teoria do garantismo jurídico penal. 2. ed. rev. e ampl. Vários tradutores e colaboradores. São Paulo: Editora Revista dos Tribunais, 2006.

FOUCAULT, Michel. Microfisica do poder. Trad. Roberto Machado. 14. ed. Rio de Janeiro: Edições Graal, 1999.

FOUCAULT, Michel. Power and knowledge: selected interviews and other writings 1972-1977. Edited by Colin Gordon. Transl. by Colin Gordon et al. New York: Pantheon, 1980.

FOUCAULT, Michel. Vigiar e punir. Trad. Raquel Ramalhete. 25. ed. Petrópolis: Vozes, 2002. GOMES, Luiz Flávio; BIANCHINI, Alice. O direito penal na era da globalização. São Paulo: Revista dos Tribunais, 2002.

GRECO, Rogério. Direito penal do equilíbrio: uma visão minimalista do direito penal. 2. ed. Niterói: Impetus, 2006.

HOBBES, Thomas. Leviatã ou matéria, forma e poder de um estado eclesiástico e civil. Tradução de João Paulo Monteiro e Maria Beatriz Nizza da Silva. São Paulo: Abril Cultural, 1979.

JAKOBS, Günther; MELIA, Manuel Cancio. Direito penal do inimigo: noções e críticas. Tradução André Luís Callegari e Nereu José Giacomolli. Porto Alegre: Livraria dos Advogados, 2005.

KARAM, Maria Lúcia. A privação da liberdade: o violento, danoso, doloroso e inútil sofrimento da pena. v. 7. Rio de Janeiro: Lúmen Júris, 2009.

NUCCI, Guilherme de Souza. Manual de direito penal. 2. ed. São Paulo: Revista dos Tribunais, 2006.

OLSSON, Giovanni. O poder político no espaço global: o protagonismo dos atores não estatais. IN: OLIVEIRA, Odete Maria (Org.). Relações internacionais, direito e poder. cenários e protagonismos dos atores não estatais. v. I. ljuí: Ed. Unijuí, 2014. p. 133-178. 
OLIVEIRA, Odete Maria de. Prisão: um paradoxo social. 3. ed. atual. e rev. Florianópolis: UFSC, 2003.

PARSONS, Talcott. Sociological theory and modern society. New York: The Free Press, 1967.

PINHO, Ana Cláudia Bastos de. Direito penal e estado democrático de direito: uma abordagem a partir do garantismo de Luigi Ferrajoli. Rio de Janeiro: Lúmen Júris, 2006.

PITKIN, Hanna Fenichel. Wittgenstein and Justice: on the significance of Ludwig Wittgenstein for social and political thought. Berkeley: University of California Press, 1972.

ROLIM, Marcos. Prisão e ideologia: limites e possibilidades para a reforma prisional no Brasil. In: CARVALHO, Salo de (Org.). Crítica à execução penal. 2. ed. Rio de Janeiro: Lúmen Júris, 2007. p. 77-110.

THOMPSON, Augusto. A questão penitenciária. Rio de Janeiro: Forense, 2002.

WEBER, Max. Economia e sociedade: fundamentos da sociologia compreensiva. v. I. Tradução de Regis Barbosa e Karen Elsabe Barbosa. Brasília, DF: Editora Universidade de Brasília; São Paulo: Imprensa Oficial do Estado de São Paulo, 1999a.

WEBER, Max. Economia e sociedade: fundamentos da sociologia compreensiva. v. II. Tradução de Regis Barbosa e Karen Elsabe Barbosa. Brasília, DF: Editora Universidade de Brasília; São Paulo: Imprensa Oficial do Estado de São Paulo, 1999b.

ZAFFARONI, Eugenio Raúl; PIERANGELI, José Henrique. Manual de direito penal brasileiro. v. 1, parte geral. 6. ed. rev. e atual. São Paulo: Revista dos Tribunais, 2006.

Informação bibliográfica deste texto, conforme a NBR 6023:2002 da Associação Brasileira de Normas Técnicas (ABNT):

OLSSON, Giovanni; CASTALDI, Valquíria. O poder do Estado no uso da violência legitima: um olhar sobre o sistema prisional brasileiro e sua (in)efetividade. Direitos Fundamentais \& Justiça, Belo Horizonte, ano 12, n. 38, p. 46-73, jan./ jun. 2018.

Submetido: 31.08.2017

Pareceres: 06.01.2018, 18.02.2018, 26.02.2018

Aprovado: 07.03.2018 